\title{
LXI. Explanation of an experiment on tuning, in reply to a correspondent
}

M.

To cite this article: M. (1811) LXI. Explanation of an experiment on tuning, in reply to a correspondent, Philosophical Magazine Series 1, 37:157, 358-360, DOI: $10.1080 / 14786441108563300$

To link to this article: http://dx.doi.org/10.1080/14786441108563300

曲 Published online: 18 May 2009.

Submit your article to this journal $\sqsubset \pi$

Џ Article views: 2

Q View related articles $\sqsubset$ 
preference over other yellows, on account of the small quantity of it which is requisite.

When mixed with gum, this substance might give a much purer and much nore solid yellow than camboge.

From this examination of gum ammonia, it results that 100 parts are composcet as follows:

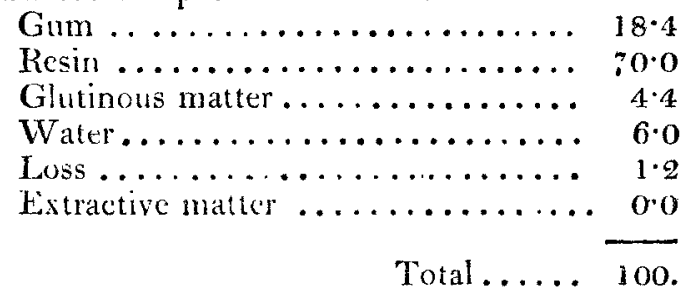

LXI. Explanation of an Experiment on Tuning, in Peply to a Correspondent. By $\mathrm{M}$.

Sin, I $\mathbf{T}$ was not till late in April that $I$ had the pleasure of receiving your Number for the preceding month, otherwise I sbould have sent you the following remarks at an earlier period.

If the author* of art. xxxii. will, uninfluenced by passion, re-examiue my letter on modes of tuning, (vol. xxxvii. p. 111), he will not discover any expressions to justify the charge of my having asserted the accuracy and success of a hasty experiment, there faithfully described; of my having given any estimate of the power of any description of monochord; nor of my having made a boast of any skill of my own: after due consideration, it will therefore appear that, instead of opposing my assertions, instead of controverting opinions which I have stated, this disceming writer has, in the elegant article referred to, been combating the mere creatures of his own disturbed imagination. We at the conclusion of the experiment, were, I think, as fully sensible as that very ingenious writer may be, of its errors; and I should have inserted a table of the differences between the scale of sounds produced and the system attempted, had I been disposed to waste your valualle pages on unnecessarv schoolboy-calculation. I repeat, that with practice, and by employing longer lime, the errors would be

* I sball cousider the Rev. C. I. Smyth to be the author, till I am better informed. Puhaps the person who could write it, will not be ashamed to arow himalf the author. 
less; if it were necessary to have recourse to such a method. But, although I have said that the majority of practical tuners are not guided by calculation, and that therefore such persons are not completely qualified to determine which is the best of the numerous unequal temperaments alreads published; I have nowhere affirmcd that they tune by the mulody. Nor have I ever imagined that the differences of monochord-leugths are proper measures of the intervals. This person boldly asserts, but for what purpose I cannot discover, that "tuners never resort to the melody in tuning." How then, let me ask him, is a tuner enabled to perceive whether the "conchord" which he is tempering be a fifih or a fourth? It is probable that his answer will not be hostile to what I have before advanced. I once saw a professional tuner much embarrassed in a first attempt to adjust the bi-equal thirds* of the Stanhope temperament; not perceiving, till he had recourse to the melody, that one of his thirds was beating flat.

It is with most tuners by profession as with the composer Grétry ; who, after declaring himself ignorant of calculation, and describing his method of tuning by thirds, by fourths, fifths, sixths, and octaves, adds, "C'est alors un tempérament de sentiment qui guide l'oreille, et non celui de calcul." (Essais, vol. ii, p. 362). Their rule is the same as Keller's; namely, to make all the IIIds as sharp, and all the Vths as flat, as the ear will permit. - See Holder's Harmony, 8vo, 1731; and Catalisano's Grammatica Armonica, 1781, p. 78 and $\mathrm{p} 156$.

In my last communication, F.750 instead of $F \cdot 749$, is an error of transcription. The following asterisk should have referred (as well as the first) to Chiadni's Acoustics, wherein the lengths for the equal temperament are: C1.00000, C or Db.94387, D89090, D $\$ 44090, \mathrm{E} 79370$, F74915, F*707 10, G66742, G*62996, A59461, A $\times 56123$, B52973, C50000, p. 37, §26.

The monochord we employed was constructed to determine the lengths of wire more minutely than your correspondent seems to have supposed; but owing to an accident, it could not be depended on to more than three places of decimals: three were therefore preferred to more, having only the semblance of greater accuracy. From this, he very logicaily concluded that we were quite ignorant of his seeming profundities.

To conclude, I leave Mr. Smyth to the arrangement, as

* See Mir. Firey's article "Bi-equal," in the Edinburgh Encyclop. vol. iii. p. $417,(18: 1$. 
to the enjoyment of his feast of palatalle dishes, as long as he is without the power of obliging me to conform to his tasie; but expecting that, when be publicly holds up one system as better than others, he should give sufficient reasons for the preference: and I assure your correspondent, that whatever title be may next apply to himself, or to his opponent, will to me be a matter of the purest indifference. May 1,1811 . A. Merrick.

LXII. Method of procuring Turpentine and other Products from the Scotch Fir. By Mr. H. B. WAY, of Bridpurt Hrlour*.

SIR, ' $\Gamma_{\text {HE enormous high price of turpentine, tar and }}$ pitch, last year, brought to my remembrance that I bad, in 1792, when in America, made some meanorandums on the subject of obtaining thom in North Carolina, which, on referring to, led me to think that they might be obtained in this country. I was induced 10 mention it to my relation and friend, John Herbert Brow n, Esy. of Weymouth, and of Sheen, in Middlesex, when on a visit at my house, and $I$ expresscd a wish that I could try the experiment with regard to turpentine; when he very kindly gave me leave to try it on three trees growing on his estate, about three or four miles from this place, and he went with me and fixed on them, and early in last April I had them prepared for the purpose of extracting the turpentine, and they have been ruming till the 1 sth instant. The wcather, except the last month and part of this, has, from so much rain falling, and there being so little bot wealber, been particularly unfarourable for this business, as, the distance being such as 10 prevent the trecs being regularly attended, the hollows were frequently found by my men full of water, and a good deal of the turpentine, which ran off with the water, lay on the ground. Under all these circumstances I was only able to obtain from the three trees about two pounds and a half of turpentine. Mr. Brown being with me again the 16 th and 17 th instant, as be wished to take the trees down, I begged he would allow me to take a part from one of them, for the purpose of scudiur to the Society of Arts, Manuiactures, and Commerce, with the turpentine collected from the trees; which he must readily complied

* From Transactions of the Shciety for the Encourngement of Arts, Mramufartires, and Commerce, vol. xxviii_- The Society voted the silver medal to Mr. Way for this communication. 